\title{
Selfie dan Media Sosial pada Seni sebagai Wujud Eksistensi
}

\author{
Michael HB Raditya'
}

\begin{abstract}
This article discusses the existence of individuals that are constructed based arts events. Selfie and social media in arts as a form of existance is the right word to respons upon the development of society. There is a issues would be discuss in this article; discuss about elements of arts existence, commodification of arts, and patterns of consumption. Literature review and ethnography is the method to solve the problem, with qualitative research. The restult of this article are; selfie is the new practice of arts consumption, social media as a field of existence, arts became a major commodity in society. The exchange not only enjoy arts object, but also there is technology that aims to increase its existence. Social media is new field for society to show the existence, and when someone selfie with art, would be more prestige. Arts became exist with a different way.
\end{abstract}

Keywords:

art; life style; existence; social media; selfie.

\begin{abstract}
Abstrak
Artikel ini membahas eksistensi individu yang dikonstruksi berdasarkan perhelatan seni. Selfie dan media sosial pada seni sebagai wujud eksistensi merupakan kata yang tepat untuk menyikapi perkembangan eksistensi masyarakat. Persoalan yang diangkat membahas eksistensi seni, komodifikasi seni dan pola konsumsi masyarakat. Metode yang digunakan yakni studi literatur dan metode etnografi, dengan penelitian kualitatif. Hasil yang ditemukan adalah praktek baru dalam mengkonsumsi seni yakni selfie, media sosial sebagai ranah eksistensi, masyarakat menjadikan seni menjadi komoditas utama. Pertukaran seni tidak hanya menikmati karya tetapi terdapat teknologi yang betujuan dalam memperkuat eksistensi. Masyarakat saling beradu eksistensi dengan media sosial yang berobjekan seni. Seni semakin eksis tetapi dengan cara yang berbeda.
\end{abstract}

\section{Kata Kunci:}

seni; gaya hidup; eksistensi; media social; selfie.

\section{Pendahuluan}

Sekitar tiga orang perempuan datang dan memasuki ruangan. Tidak seperti orang lainnya yang bicara secara perlahan dan berbisik. Mereka berbicara dengan suara yang cukup lantang, disertai gelak tawa dan ramai. Sebenarnya tidak ada salahnya jika mereka ramai, toh ini bukan di tempat ibadah atau sedang melakukan doa yang suasananya harus khusyuk. Ketiga orang perempuan

\footnotetext{
- Dosen Jurusan Etnomusikologi, Institut Seni Indonesia(ISI), Yogyakarta.

Email: michael.raditya@gmail.com
} 
itu clingak-clinguk, ke kiri dan ke kanan, mereka menunjuk ke salah satu sisi ruangan, sementara temannya membantah, temannya lalu menambahkan dan menunjuk ke arah yang sebaliknya. Akhirnya mereka seperti membuat kesepakatan dengan mengitari semua sisi ruang. Yang berbeda dengan lainnya, mereka mengitari dengan cepat sisi ruang, seperti mencari sesuatu yang menarik. Pada salah satu sisi ruang, mereka berdiskusi, "ini lho bagus, warnanya banyak, gambarnya lucu", sementara temannya mendukung, tetapi teman lainnya lebih menawarkan sisi lainnya yang lebih berwarna, besar, dan objek gambarnya lebih menyenangkan karena menggambarkan kartun. Diskusi berakhir, mereka berjalan dengan cepat ke arah gambar tersebut dengan melewati karya-karya lainnya. Lalu, menimbang-nimbang sejenak, berdiri di kiri dan kanan gambar, mereka seperti mengatakan "oke ini bagus!". Yang satu mengeluarkan sebuah tongkat, yang beberapa tahun belakangan ini digandrungi, dikenal dengan "tongsis", singkatan dari tongkat narsis. Mereka menarik tongsis dengan sudut pandang terpanjang, meletakan handphone pada tongsis dengan kualitas kamera yang terbaik, mengepaskan mereka bertiga di depan objek gambar, lalu mereka mengabadikannya, "crekk". Di saat itulah baru tidak terdengar suara gaduh ramai dari mereka, bak anak kecil yang diberi mainan, diam. Mereka mengabadikannya tidak sekali, lebih dari tiga kali untuk mendapatkan angel terbaik. Setelah itu mereka mengitari karya secara random dan keluar dari ruangan secara sopan. Sekeluarnya mereka dari ruangan, suasana kembali sepi walaupun masih ramai dengan pengunjung lainnya. (pengamatan sebuah pameran di Jogja Gallery, Mei 2014)

Sore itu terdapat sebuah pembukaan pameran di Jogja Gallery, tepatnya sebelah timur laut dari alun-alun utara Yogyakarta. Sebuah pameran dengan judul "Rupanada" dihelat pada bulan Mei silam. Para penikmat rupa mulai memadati ruang pameran. Pengap terasa karena padatnya ruang pamer dengan para pengunjung. Pengunjung tidak didominasi oleh kategorisasi tertentu, tua - muda, baik laki-laki dan perempuan berbaur menjadi satu. Karya demi karya dinikmati oleh para pengunjung tanpa terkecuali. Ketika saya menikmati karya -dengan mengitari ruang pamer-berbagai macam cara dalam menikmati karya dapat terlihat dengan jelas, seperti, mengitari karya secara cepat tetapi berkalikali, menikmati karya perlahan, hingga sebuah cara baru yang saya temui dalam praktek konsumsi seni, yakni berfoto dengan karya yang dipamerkan. Berfoto dengan objek seni menjadi sebuah fenomena baru dalam mengkonsumsi seni itu sendiri.

Seperti catatan etnografis yang saya lampirkan di awal tulisan, bahwa terdapat tiga orang remaja yang mengabadikan diri mereka dengan karya lukis yang dipamerkan pada sebuah pameran. Berbeda dengan orang-orang kebanyakan dalam menikmati karya seni, mereka mengabadikan karya dengan diri mereka. Beberapa orang memang menyayangkan dari cara menikmati karya mereka, terlebih para expert seni atau penikmat setia seni, tetapi tindakan anak-anak remaja ini juga bukanlah sebuah kesalahan atau tindakan yang dilarang. Dalam artian menikmati seni, semua orang bisa menikmati karya dengan cara mereka masingmasing, dengan asumsi para pengunjung dapat meresapi dan menikmati karya dengan berkualitas. Ihwal ini toh tidak hanya dilakukan oleh ketiga remaja itu, dalam setiap gelaran seni baik pameran atau pergelaran pertunjukan, kerap kita jumpai seorang atau sekelompok orang melakukan tindakan serupa. Tidak dapat dipungkiri bahwa tindakan ini menjadi pola konsumsi baru dalam menikmati seni.

Ihwal ini merupakan sebuah fenomena baru dalam menikmati karya seni, tidak hanya dengan berdiam, merenung, layaknya refleksi atau kontemplasi semata, tetapi ada tindakan lain dalam menikmati sebuah karya. Cara 
menikmati seni dengan gaya baru ini tidak serta merta terjadi, tindakan ini disokong dengan kemajuan teknologi. Jika diartikan lebih mendalam, tindakan ini merupakan manifestasi budaya dari dinamisnya masyarakat. Masyarakat yang terus berkembang menerima gagasan dan kebudayaan baru yang dipadupadankan, lalu mengaplikasikannya ke dalam kehidupan seharihari. Cara baru menikmati seni ini tidak menjadi soal jika cara mengabadikan diri dengan objek seni benar-benar diartikan untuk menikmati seni, yang menjadi soal ketika tindakan ini tidak ditujukan untuk menikmati seni, tetapi eksistensi semata. Ihwal ini layaknya pisau bermata dua, ketika seni menjadi komoditas paling laris dari masyarakat maka eksistensi dari seni itu sendiri tidak patut dipertanyakan keberadaannya, tetapi di sisi sebaliknya, nilai seni itu sendiri yang semakin dipertanyakan. Di satu sisi, sudah barang tentu seni menjadi kebutuhan yang penting bagi masyarakat, tetapi sisi lainnya, ihwal ini akan berimplikasi buruk pada nilai seni itu sendiri, dan tidak bisa dibayangkan ketika tindakan ini berlangsung kontinu, maka nilai seni dari karya akan tergadaikan oleh masyarakat dengan tipe penikmat baru ini.

Terbetik dari persoalan ini, artikel ini merupakan wujud kegelisahan penulis terkait pola konsumsi seni dewasa kini. Realitasnya, masyarakat Yogyakarta (pada tataran remaja dan dewasa) menjadikan seni sebagai komoditas utama pada ranah hiburan mereka. Thwal ini pun didukung dengan masifnya acara yang dihelat di Yogyakarta. Keadaan ini dapat diartikan bahwa kuantitas acara seni di Yogyakarta meningkat seiring dengan konsumsi seni yang meningkat. Oleh karena itu, artikel ini akan membahas lebih dalam tentang pola konsumsi seni masyarakat. Persoalan yang diangkat akan membahas; komoditisasi seni yang menjadi gaya hidup dan pola konsumsi masyarakat pada seni itu sendiri.

Untuk menjawab persoalan akan digunakan beberapa telaah teoritis terkait permasalahan, seperti pola konsumsi dan komoditas seni, yang menyebabkan kuantitas konsumsi seni yang membludak. Persoalan ini menjadi sangat penting mengingat hakikat seni yang terus berubah seiring dengan dinamisnya tindakan manusia. Seni yang diartikan Jakob Sumardjo sebagai media refleksi masyarakat (2000:241), patut dipertanyakan keberadaannya kini. Asal mula seni sebagai produk dan pemroduksi masyarakat menjadi biner. Telaah Arnold Hauser yang menyatakan seni merupakan produk masyarakat untuk menunjang kehidupan (1982), menjadi semakin gamang, terlebih masifnya produksi seni yang terkadang didasarkan pesanan, dan meningkatnya konsumsi seni sebagai wujud eksistensi atas kepentingan semata,

\section{Metode Penelitian}

Dalam menjawab persoalan, metode yang digunakan adalah kajian pustaka dan metode penelitian etnografi dalam mengintepretasikan eksistensi pada seni. Studi literatur digunakan dalam mengeksplorasi dan mempertajam data yang didapat. Sedangkan metode penelitian etnografi merupakan ragam pemaparan penelitian budaya untuk memahami cara orang-orang berinteraksi dan bekerjasama melalui fenomena teramati dalam kehidupan sehari-hari (Spreadley, 2007:5). Deskriptif analitis akan memberikan sebuah pemahaman baru bagi para pembaca. Teknik pengumpulan data yang dilakukan adalah kualitatif, dan dirasa dapat membantu dengan tepat dalam kebasahan untuk menjawab pertanyaan. Hasil temuan akan menjadi refleksi dalam melihat eksistensi seni pada masyarakat sebagai sebuah manifesto kebudayaan.

\section{Pembahasan}

\section{"Selfie" dan Posting Seni Sebagai Arena Eksistensi}

Akhir-akhir ini, selfie menjadi sebuah tema yang kerap kita dengar, terlebih bagi anak-anak muda dalam tataran remaja dan 
dewasa yang sangat akrab dengan tindakan ini. Selfie itu sendiri berasal dari kata self yang diartikan sebagai diri. Selfie tidak berbeda dari kata yang lebih dikenal sebelumnya, yakni narsis. Selfie merupakan tindakan dalam mengabadikan diri pada sebuah momen yang dianggap penting oleh si individu. Dalam perkembangannya selfie menjadi gaya hidup baru bagi masyarakat, tanpa mengenal usia, tua atau muda, semua melakukan tindakan ini. Tidak tanggung-tanggung, dalam menyokong tindakan selfie ini tercipta sebuah tongkat panjang untuk menyangga kamera handphone di sisi tongkat lainnya. Tongkat ini dikenal dengan sebutan "tongsis", atau dikenal dengan tongkat narsis. Komoditas tongsis merajalela, dan hampir dipastikan bahwa pada sekelompok anak muda, terdapat seorang yang mempunyai tongsis. Terlebih jika kita pergi ke tempat hiburan atau tempat wisata, dapat dipastikan tongkat ini kerap kita jumpai, yang secara otomatis para pemilik tongkat ini akan melakukan selfie.

Dalam keberlangsungannya, hasil dari selfie tidak lagi dinikmati secara pribadi oleh orang yang melakukan selfie tersebut. Kemajuan teknologi membuat mereka mengupload atau memposting hasil selfie mereka ke media sosial yang ada. Dunia maya sangat signifikan dalam perkembangannya, kini dapat dijumpai media sosial yang menyediakan dan memamerkan posting selfie pribadi ke ranah publik. Secara otomatis, ihwal ini merupakan penyebarluasan arsip pribadi yang menjadi arsip publik. Tanpa filter, semua foto dapat diupload ke media sosial, dan dinikmati oleh orang banyak. Secara implisit, sudah dapat dipastikan bahwa media sosial menjadi arena eksistensi mereka untuk memposting foto selfie dengan moment terbaik yang mereka punya. Semakin sebuah moment mengandung nilai yang prestisius, maka individu yang memposting foto selfie tersebut semakin eksis.

Praktek selfie dan posting di dunia maya yang semakin masif membentuk sebuah pola baru. Ketika pada awal ketenaran selfie, setiap individu mengabadikan dirinya baik pada moment tertentu atau sebaliknya, tetapi kini, para pelaku selfie tidak melakukan selfie di sembarang tempat. Mereka seakan mengerti tempat atau kegiatan apa yang akan membuat mereka terlihat semakin terlihat eksis. Pada tataran ini, peristiwa seni menjadi target operasi para pelaku selfie. Tidak tanggung-tanggung, mereka melakukan praktek selfie dengan karya seni yang ada. Catatan etnografis di awal tulisan merupakan salah satu contoh nyata dari tindakan selfie dengan objek seni. Ihwal ini pun tidak dapat diartikan sebagai intimidasi terhadap objek seni, karena dengan tindakan selfie ini, eksistensi dari objek seni pun turut terbentuk di media sosial. Atas disposisi yang terjadi, semua tindakan ini berimplikasi pada mapannya sebuah eksistensi. Dalam tatarannya, eksistensi pada gaya hidup menjadi primadona bagi konsumsi masyarakat dewasa kini. Secara implisit, terjadi perubahan pada seni dan artian seni, yang biasanya ditentukan oleh penyaji, kolektor, atau penikmat setia, maka kini masyarakat awam pun turut mengkonsumsi seni, walaupun dengan tajuk yang berbeda, eksistensi.

Jika bertolak ke beberapa dekade silam, seperti pada karya lukis yang berobjekan pemandangan yang menjamur sejak abad 19 hingga 20, lukisan jenis pemandangan yang disebut Mooi Indie (Indonesia Molek) sangat digandrungi pelukis dan kolektor ketika itu. Tekstual dari lukisan gaya ini mengeksplorasi panorama dan beberapa kegiatan masyarakat, sebagai contoh; pemandangan pegunungan, pantai, wajah perempuan Bali, dsb. Sedangkan kontekstualnya, kondisi "gandrung" mooi indie dikonstruksi oleh para kolonialis, dengan maksud memperlihatkan keadaan yang baik-baik saja di bawah kolonialisasinya. Pangsa pasar gaya lukis panorama menjadi komoditas seni pada saat itu. Semua gaya lukisan didominasi oleh gaya mooi indie. Gaya lukis lain kurang diminati khalayak banyak. 
Mooi indie mengkonstruksi masyarakat dalam romantisme akan Indonesia indah. Konstruksi tersebut -lewat para pelukis dan kolektorberimplikasi pada konsumsi gaya lukis masyarakat. Ihwal ini pun dirasakan penulis ketika melihat lukisan-lukisan yang dimiliki oleh masyarakat. Biasanya, masyarakat -baik pecinta lukisan atau penikmat- mempunyai lukisan gaya pemandangan Indonesia di rumahnya, seperti panorama pegunungan, pantai, sawah, dsb. Terkait dengan ihwal tersebut, keberhasilan akan konsumsi gaya mooi indie oleh masyarakat, didasarkan pada produksi dan distribusi yang kuat pula. Ihwal ini dibuktikan dengan pernyataan Sudjojono bahwa:

\section{Gunung, pohon, kelapa serta sawah adalah trinitas yang kudus dalam pemandangan dari para seniman, dan bila seorang pelukis melukis sesuatu yang berbeda dari trinitas ini, pedagang seni akan mengatakan dat is niet voor ons, meneer atau ini bukan untuk kami, tuan. (dalam Holt, 2000:279)}

Tidak dipungkiri bahwa gaya panorama menjadi status quo pada saat itu. Bahkan Sudjojono mengasumsikan trinitas kudus lukisan pada masa itu, yang keseluruhannya mengarah pada pemandangan, seperti; gunung, pohon, kelapa serta sawah. Trinitas ini dilegitimasi oleh para distributor (pedagang seni) sebagai selera pasar pada saat itu. Gaya selain pemandangan akan ditolak untuk diperjualbelikan oleh distributor.

Ihwal inilah yang menjadikan Sudjojono (pelukis) untuk meng-counter gaya mooi indie, dengan dalih implikasi buruk pada mental masyarakat untuk menutup mata dari realitas sebenarnya. Sudjojono mempercayai bahwa seorang seniman membuat suatu barang kesenian, maka sebenarnya buah kesenian tadi tidak lain dari jiwanya sendiri yang kelihatan (Sudjojono, 2000:92). Pernyatan Sudjojono yang dikenal dengan Jiwa Ketok ini merupakan representasi dari implikasi dalam meng-counter lukisan mooi indie. Resistensi Sudjojono mengarah pada ketidakjujuran pada keadaan dan mandulnya perhatian seniman yang diharapkan sebagai agent of change pada jiwa zamannya. Gaya lukisan mooi indie sudah berlangsung sejak abad-19 hingga 20, salah seorang yang terkenal dengan gaya ini adalah Raden Saleh. Satu abad gaya mooi indie melahirkan banyak pelukis gaya naturalis di Indonesia.

TindakanSudjojonomemang mengganggu kenyamanan dari gaya lukisan mooi indie, alhasil gaya tersebut tumbang ketika Sudjojono menstimulasi secara universal pelukis dan perupa lainnya untuk memberontak dengan gaya Realisme. Semenjak itu, gaya realisme merupakan gaya yang diacu oleh para pelukis dan menjadi pangsa pasar distributor. Bila ditelaah secara lebih mendalam, terdapat trayektori atas struggle (menilik pemikiran Bourdieu (1996) atas Field of Struggle-nya) sebuah gaya lukis dalam membentuk pola eksistensinya. Pertarungan modal kultural pada sebuah gaya lukis terjadi pada ranah pertarungan (field of struggle), mereka yang bertahan dan dapat mempertahankan trayektorinya akan terjaga dan dominan.

Bertolak dari realitas mooi indie hingga realisme ala Sudjojono, eksistensi seni belakangan ini mempunyai nasib yang mujur. Dalam ihwal ini, mujur dapat diartikan sebagai wujud kegemilangan dari seni, atau seni sedang di puncak eksistensinya. Dibarengi dengan meningkatnya produksi dan konsumsi seni itu sendiri, terbentuk sebuah peran baru dalam menentukan eksistensi seni, yakni masyarakat awam. Berselfie dan memposting hasil selfie mereka ke media sosial memberikan dampak terhadap eksistensi seni semakin kuat. Tidak hanya seorang individu mencapai eksistensinya dalam top performanya, tetapi turut berimplikasi pada objek seni yang diabadikan dan disebarkan di media sosial. Walaupun seni tidak dapat diartikan seperti 
telaah Tolstoy pada buku What is Art? tahun 1960 yang mengartikan seni sebagai sebuah aktivitas manusia yang dipertimbangkan dari kesadaran yang distimulasi dari penandaan, perasaan yang menyeluruh, empati dari sebuah perasaan dan pengalaman seseorang. Atau bisa diartikan sebagai wujud stimulasi dari penubuhan yang termanifestasi dalam tubuh. Tetapi seni dalam tataran ini mempunyai artian nilai yang baru oleh masyarakat.

Walaupun konsumsi seni dengan berselfie dan posting di media sosial menjadi sebuah kebiasaan baru masyarakat, yang kebanyakan berasal dari masyarakat awam, ihwal ini menuai banyak pro dan kontra dalam keberlangsungannya. Bagi Muhammad yang seorang mahasiswa seni, ia mengatakan bahwa:

"Tidak habis pikir sih mas, dengan anakanak jaman sekarang yang selfie dengan objek karya lalu langsung pulang, tidak melihat semua karya. Kalau menurut saya sih, melihat karya ya perlahan, dan agak konyol kalau cepat-cepat lalu foto langsung pulang, ketauan tidak menikmati karya tapi pengen foto doang." (20 November 2014)

Bagi Muhammad yang mengerti seni dan memahami seni sebagai sesuatu yang adiluhung, terlebih cara menonton seni yang didasarkan pada pemahaman lebih di depan karya, yang bahkan memakan waktu lebih dari lima menit di depan karya, atas fenomena baru menikmati seni dengan berselfie menjadi sebuah kegiatan yang tidak masuk akal. Secara implisit pendapat Muhammad secara tegas melegitimasi tindakan selfie dengan objek seni bukanlah cara menikmati seni. Ihwal ini jelas berbeda dengan Yanti, seorang pelajar SMA yang melakukan selfie di depan objek seni. Yanti mengisyaratkan bahwa dirinya melakukan selfie dengan objek seni lebih dari satu kali, bahkan menjadi sebuah "candu eksistensi". Yanti mengatakan bahwa:

\begin{abstract}
"Aku tidak tahu mas apa artinya ini, kok gambarnya banyak (karya Nasirun) dan beda-beda, aku tidak ngerti mas, tapi ya foto aja soalnya bagus, habis itu di posting di social media deh. Terus dikomenin banyak orang, tanya itu dimana?, bagus, lucu."(18 Juni 2014)
\end{abstract}

Atas apa yang telah dilakukan oleh Yanti, jelas ia tidak mengerti seni seperti Muhammad. Ketertarikan Yanti dapat didasarkan pada objek seni yang menarik, dan berbeda. Yanti mengartikan ketidakpahamannya dengan cara mengabadikan dirinya dengan objek karya tersebut. Tidak hanya itu, Yanti turut memposting hasil foto selfie-nya ke media sosial, dan menuai komentar dari relasinya yang ada di media sosial tersebut. Walaupun Yanti tidak paham dengan objek seni yang dipamerkan, tetapi Yanti turut mempromosikan karya yang diabadikannya. Ihwal ini jelas salah bila mengenakan perspektif Muhammad, tetapi akan benar jika menggunakan perspektif Yanti. Diantara perspektif Muhammad dan Yanti, terdapat perspektif lain, Ratna mengatakan bahwa

\section{"Kurang setuju juga, lihat karya cuma foto selfie tanpa melihat karya dengan serius, tetapi ya gimana kemajuan zaman, lagipula karyanya juga ikut eksis sih walau dengan cara seperti itu, sekarang mau gimana lagi, sudah tidak bisa dicegah juga, apalagi semua orang hapenya canggih." (21 November 2014)}

Secara eksplisit Ratna mengemukakan ketidaksetujuannya terhadap laku selfie dengan objek seni, tetapi di sisi lain, Ratna tidak dapat mencegah tingkah laku ini karena didasarkan pada kemajuan teknologi dan konsumsi eksistensi yang semakin bervariasi. Bahkan bisa saja pada suatu saat Ratna pun turut melakukan selfie dengan karya.

Dalam sudut pandang Muhammad, Yanti dan Ratna, mereka secara jelas mengutarakan 
keberpihakan pada selfie, ketidaksetujuan atas selfie, atau menyerah atas ihwal ini. Fenomena selfie ini memang tidak dapat dihindarkan. Kita boleh saja bersikap dalam keberpihakan atas fenomena tersebut, tetapi kita harus bersikap secara bijak dan berfikir terbuka. Sebenarnya poin yang menarik disini adalah mengakali tindakan selfie untuk lebih beradab. Beradab dapat diartikan sebagai paham dan mengerti seni. Senada dengan gagasan ini, Agus berpendapat atas fenomena ini:

\section{"Ya melihat fenomena banyak anak abg yang sekarang ke galeriatau pertunjukan lalu berfoto sih bukan masalah ya, toh aku percaya secara sadar atau tidak sadar dia mengenal seni walaupun dengan cara seperti itu, nantinya akan terpikirkan sih, dan efek panjangnya semoga bagus." (30 September 2014)}

Perspektif Agus dalam menyikapi fenomena ini sangatlah positif. Agus percaya bahwa tingkah laku ini suatu saat akan menjadi modal paham seni di kemudian hari. Ihwal ini seperti gagasan Pierre Bourdieu (1996) atas habitus, modal, ranah dan praktiknya, dimana sebuah tindakan atau tingkah laku didasarkan pada sebuah pembelajaran baik secara sadar ataupun tidak sadar, dan implikasi terbentuk dari pembelajaran yang akan menubuh baik secara langsung atau tidak langsung.

Selfie dan posting seakan membentuk sebuah korelasi yang tidak dapat terpisahkan. Media sosial berperan sangat penting dalam berselfie yang tujuannya meraih eksistensi. Dari cara menikmati karya dengan berselfie dengan objek seni, jangan-jangan di masa depan sebuah pameran juga dihelat di media sosial. Media sosial memegang peranan yang besar dalam mendukung praktek selfie, terlebih tersedia aplikasi-aplikasi pada media sosial seperti: Facebook, Twitter, Instagram, dsbnya. Media sosial membuat cara menikmati karya dengan berselfie semakin primer. Media sosial melegalisasi tindakan berselfie di depan objek seni. Dengan keberadaan media sosial, yang merupakan legitimasi dari masyarakat awam sebagai reseptor seni, terjalin sebuah skema baru dalam mengkonsumsi seni, yakni produsen, distributor dan konsumen seni. Produsen seni adalah para seniman yang memamerkan karya atau menggelar pertunjukan, konsumen adalah masyarakat (masyarakat paham seni, penikmat seni, dan masyarakat awam), dan distributor seni, yakni media sosial dan penyebar berita di media sosial. Dalam ihwal ini, peran media sosial menjadi peran sentral dalam eksistensi individu pengunggah selfie dan seni itu sendiri. Menurut Eriyanto, media massa menjadi tempat warga dapat saling berdiskusi mengenai suatu isu secara bebas. Media mengangkat isu yang terjadi di dalam masyarakat, mengangkat suara dan pendapat masyarakat dan menampung berbagai umpan balik yang muncul (2008:123). Media menjadi tempat bersilahturahmi secara virtual. Jika bisa dislogankan, media adalah wadah untuk mendekatkan mereka yang jauh.

Kembali pada persoalan distributor seni, media sosial bisa diposisikan sebagai distributor eksistensi, tetapi juga dapat dikatakan sebagai produsen citra dari eksistensi. Belakangan ini, yang terjadi pada media sosial adalah produsen citra dari eksistensi untuk para konsumen seni. Media sosial merupakan wadah berbagi informasi yang tidak dibatasi dalam ruang dan waktu. Para penggeraknya adalah para pengunggah foto selfie dan penyebar berita seni yang menjadi pusat informasi dari para konsumen seni. Seperti ihwalnya konsep yang ditawarkan Ben Anderson terkait komunitas terbayang-nya, bahwa terdapat kesamaan yang menyatukan sekelompok masyarakat untuk bekerja dan bergerak secara kolektif (1991). Dalam ihwal eksistensi seni, kesamaan ini didasarkan pada dasar informasi seni. Eksistensi pada gaya hidup didasarkan pada berita seni, maka para pelaku selfie seni berlomba-lomba dalam mengakses acara seni. 
Distributor seni di media sosial didasarkan pada aplikasi media sosial yang digunakan. Sebagai contoh, pada media Facebook terdapat beberapa akun (profile) yang menyebarluaskan berita seperti; akun a/n Seni Tradisi Yogyakarta, akun a/n Informasi Seni Yogyakarta, dsb. Pada media Twitter terdapat beberapa akun (profile) serupa seperti; infosenijogja, beranda jogja, dsbnya. Beberapa akun menyebarluaskan informasi acara dan gambar ketika acara tersebut sedang berlangsung.

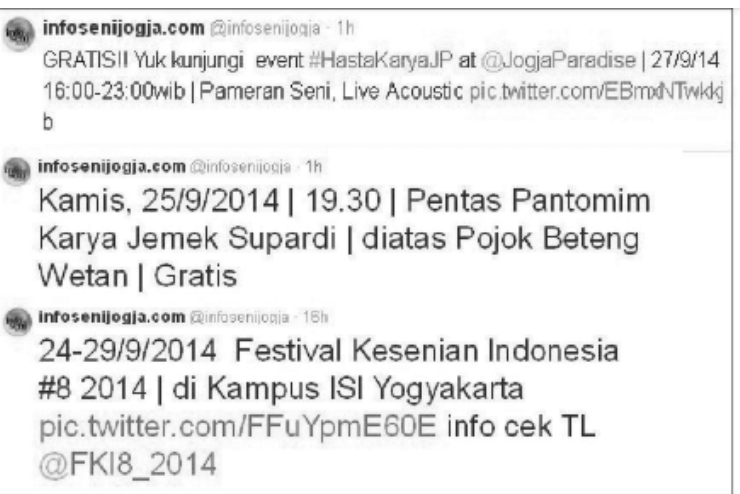

Informasi yang disebarluaskan didasarkan pada informasi jurnalistik seperti $5 \mathrm{~W} 1 \mathrm{H}$ (What, Who, Where, When, Why dan How). Biasanya informasi yang didistribusikan berisikan; acara apa yang dihelat; siapa pengisi acara; dimana tempat perhelatan; kapan waktu perhelatan; dan bagaimana mengakses perhelatan. Informasi ini di sebarluaskan kurang lebih satu minggu sebelum perhelatan. Distributor seni ini pun turut memberikan informasi ketika acara dihelat, dengan mengirimkan foto tentang keadaan dan suasana perhelatan.

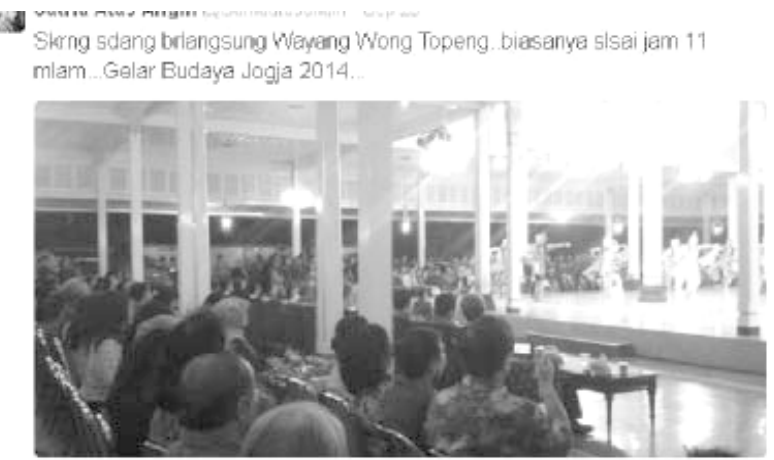

Sigum mere photos and videng
Berita lepas ini akan menstimulasi para konsumen seni untuk hadir dan meramaikan acara yang dihelat.

Secara eksplisit, distribusi seni menjadi salah satu unsur yang membentuk eksistensi seni kini semakin kuat. Eksistensi seni pada gaya hidup terbentuk didasarkan pada keterjalinan produksi, distribusi dan konsumsi pada seni itu sendiri. Singkat kata, eksistensi seni pada gaya hidup membentuk sebuah tatanan yang saling mengikat. Tatanan yang saling berfungsi satu sama lain, menstruktur dan mengkonstruksi unsur berkorelasi satu dengan yang lain, sehingga para penikmat selfie semakin leluasa dalam mengakses seni, berselfie dan mempostingnya.

\section{Konsumsi dan Keterjalinan}

Eksistensi seni padagayahidupdibentuk berdasarkan keterjalinan dan kesinergisan setiap unsurnya. Proses produksi, distribusi dan konsumsi yang masif membentuk sebuah kebiasaan pada pola masyarakat. Proses pembiasaan tersebut menjadi tren masyarakat banyak. Tren masyarakat membentuk selera kolektif yang kuat. Alhasil eksistensi terlegitimasi oleh masyarakat banyak dari tren yang digandrungi pada saat itu. Dewasa ini, gaya hidup menjadi komoditas utama, ihwal ini berimplikiasi pada fitur-fitur gaya hidup yang semakin digandrungi pula. Konsumsi semakin masif, dan apa yang dikonsumsi mengkonstruksi eksistensi dari konsumen. Terkait konsumsi itu sendiri,

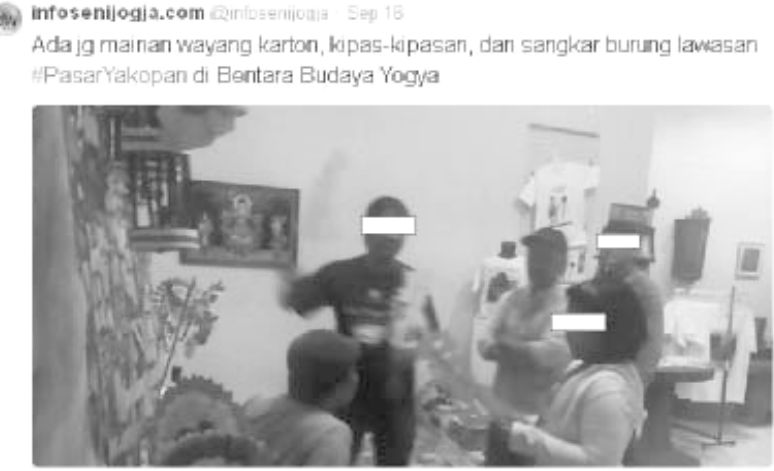

Wiew more photos and videg

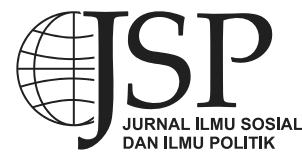




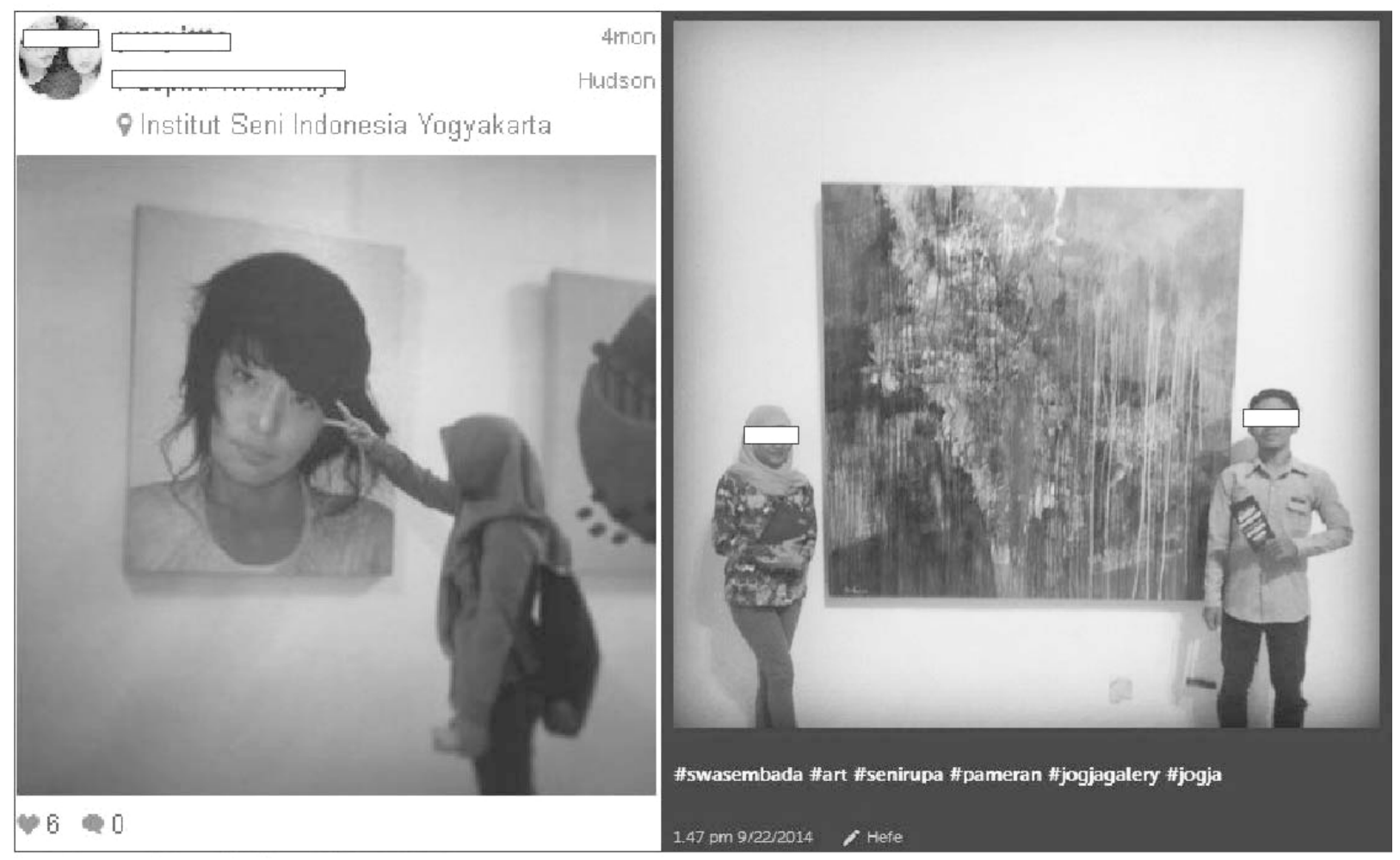

menurut Featherstone adalah Consumption and lifestyle preferences involve discriminatory judgements which at the same time identify and render classifiable our own particular judgement of taste to others. Particular constellations of taste, consumption preference and lifestyle practices are associated with specific occupation and class fractions, making it possible to map out the universe of taste and lifestyle with its structured oppositions and finely granded distinctions which operate within a particular society (Featherstone, 1995: 95). Telaah Featherstone menyatakan bahwa konsumsi dan gaya hidup melibatkan diskriminasi putusan yang pada waktu besamaan mengidentifikasi dan meperlihatkan kelas antara satu dengan yang lain. Konstelasi rasa, konsumsi dan gaya hidup berasosiasi dengan pekerjaan dan pembagian kelas. Pembagian kelas dan pekerjaan membentuk pola konsumsi dan gaya hidup dalam bermasyarakat.

Pembedaan antara yang satu dengan yang lain -dalam telaah konsumsi- memberikan pembedaan yang signifikan terhadap eksistensi pada gaya hidup. Menurut Irwan Abdullah, konsumsi tidak hanya mengkonsumsi barang, tetapi terdapat konsumsi simbolis. Konsep konsumsi simbolis yang ditawarkan Irwan Abdullah membedakan tiga kategorisasi terhadap konsumen, yakni; kelas sosial telah membedakan proses konsumsi di mana setiap kelas menunjukan proses identifikasi yang berbeda; barang yang dikonsumsi kemudian menjadi wakil dari kehadiran; proses konsumsi menjadi konsumsi citra (image) (Abdullah, 2010:34). Jelas pada pendapat Irwan bahwa kelas sosial membedakan proses konsumsi, implikasi yang diciptakan pada pengidentifikasian kelas yang satu dengan yang lain. Pembedaan tersebut dikonsumsi masyarakat untuk menunjukan "diri" mereka sebagai kategorisasi kelas tertentu. Penunjukan atas diri mereka secara implisit mengungkap bahwa yang mereka konsumsi adalah citra dari yang mereka konsumsi.

Pada ihwal ini, seni dan perhelatannya menjadi gaya hidup yang menentukan seorang individu mempunyai eksistensi yang kuat atau sebaliknya, terlebih dengan berselfie. Seperti yang telah diungkap Irwan Abdullah bahwa seni merupakan komoditas dari kelas tertentu. 
Asumsinya adalah seni merupakan komoditi masyarakat kelas atas, maka setiap individu akan berusaha mengakses pembedaan tersebut untuk membuat "pemalsuan identitas". Mereka akan memalsukan identitas kelasnya dengan mengkonsumsi apa yang dikonsumsi kelas diatasnya, terlebih penyematan kata "eksis" sangat diburu masyarakat kini. Dengan mengkonsumsi seni, mereka menunjukan bahwa diri mereka ada dan melegitimasi eksistensi yang terdapat pada seni sebagai gaya hidup.

Dari gambar diatas dapat dilihat bahwa individu mengabadikan dirinya dengan karya seni dan dikirimkan di media sosial yang ada. Cara itulah yang melegitimasi bahwa individu dikatakan eksis. Tidak hanya pada perhelatan seni rupa, tetapi juga pada seni pertunjukan. Setiap masyarakat yang datang mengabadikan diri mereka dan berselfie dengan objek seni yang dilihatnya.

Walaupun mereka tidak mengerti atas seni yang mereka lihat, bahkan tidak dapat menikmati karya seni tersebut, tetapi kehadiran seorang individu dengan objek seni menjadi wujud eksistensi yang diburu pada saat ini. Sebagai contoh pada perhelatan ArtJog, sebuah "pasar" (diartikan pasar karena "fair") seni lukis yang menghadirkan lebih dari 100 karya rupa, baik lukis, pahat, guci, dsb. Pada perhelatannya di tahun 2014 ini, ArtJog dikenakan biaya Rp 10.000 -berbayar baru dilakukan tahun ini-, dan pengunjung yang datang tidak berkurang bahkan bertambah, setidaknya 2.500 pengunjung hadir di setiap harinya (Tribun Jogja, 11 Juni). Dari perhelatan ArtJog ini, masyarakat sebanyak 2.500 di setiap harinya (merupakan angka pasti) tidak dapat dipastikan mengerti nilai seni yang mereka tonton. Bahkan kebanyakan dari mereka adalah anak di bangku SMP dan SMA yang nampak dari pakaian seragam yang mereka kenakan (observasi peneliti). Mereka melakukan foto diri dengan karya seni yang mereka anggap lucu dan bagus. Foto dan mengirimkannya ke media sosial sebagai ritual yang harus dilakukan. Tanpa memperhatikan secara rinci karya, foto sebanyak-banyaknya adalah hasil buruan mereka untuk memenangkan eksistensi. Secara implisit, seni sudah membentuk sebuah sistem konsumsi baru, salah satu bentuk dari sistem candu seni itu adalah menyebarluaskan foto diri dengan objek seni.

Citra menjadi tajuk yang diidamkan setiap masyarakat, khususnya anak remaja. Mereka menukarkan uang mereka untuk mengkonsumsi citra yang terdapat pada seni, bukan karya seni-nya. Seperti pada pendapat Yanti:

"Aku tidak tahu mas apa artinya ini,
kok gambarnya banyak (karya Nasirun)
dan beda-beda, aku tidak ngerti mas,
tapi ya foto aja soalnya bagus, habis
itu di posting di social media deh." (18
Juni 2014)

Kata "bagus" dari Yanti mengundang kejanggalan terkait penilaian dari sebuah karya. Bagus dalam artian yang sebenarnya, atau bagus di kamera? Setelah melakukan pembicaraan kembali, yang dimaksud dengan bagus oleh Yanti adalah gambar ramai, lucu dan unik (dalam perspektifnya). Penilaian didasarkan pada pemikiran individu saja, bukan estetik. Bisa dikatakan bahwa Yanti tidak mengerti objek seni apa yang dilihatnya, yang terpenting baginya adalah berfoto dengan objek dan disebarluaskan dengan media sosial. Ihwal ini semacam candu dan mempunyai daya magis dalam mengkonstruksi individu lainnya untuk melakukan tindakan yang sama. Citra seni menjadi perburuan eksistensi mereka. Bisa dikatakan bahwa bukan seni-nya yang membuatcandu, tetapi nilai eksistensi pada gaya hiduplah yang membuat candu sebagian besar masyarakat. Citra yang membuat mereka candu dan membutuhkannya untuk perwujudan diri mereka. Eksistensi menjadi komoditas utama masyarakat, dan mereka tidak segan-segan untuk mengejarnya. Perhelatan seni yang 
semakin masif menjadi objek mereka, yang membuat candu dan menjadikannya sebagai kebutuhan utama.

\section{Selfie dan Media Sosial sebagai Komodifikasi Baru}

Pada telaah sebelumnya, seni menjadi komoditas utama masyarakat dalam membuktikan eksistensinya. Singkat kata, terjadi komodifikasi pada seni yang didasarkan pada permintaan masyarakat. Seni tidak hanya mengalami transformasi pada tataran bentuk dan keberadaannya saja, tetapi juga terjadi pada nilai. Bertolak dari komodifikasi itu sendiri, pada dasarnya, Barker (2005:517) mengemukakan bahwa komodifikasi adalah hasil asosiasi proses atas kapitalisme. Terdapat tanda, objek dan kualitas yang dijadikan sebagai sebuah komoditas. Biasanya komoditas selalu berhubungan dengan pasar dan penjualan. Dapat dilihat bahwa komodifikasi merupakan transformasi dari sebuah barang yang tujuan akhirnya adalah komoditi, atau pasar. Telaah lebih lanjut yang dilakukan Smith dan Evans (2004:32-33) mengemukakan bahwa komodifikasi merupakan hasil produksi dari sebuah proses kerja yang fungsinya bukan lagi untuk dipergunakan, tetapi lebih pada nilai jual-beli. Baik pernyataan Barker, Smith dan Evans, menegaskan bahwa terdapat konsep yang lebih besar dari pada pertukaran nilai, tetapi jual beli. Pada ihwal ini, seni sebagai bentuk dari komoditas utama jual beli.

Bila Barker, Smith dan Evans lebih menitikberatkan permasalahan pada soal pembentukan nilai tukar menjadi jual beli. Fairclough (1995:207) menyatakan bahwa komodifikasi merupakan sebuah proses aktivitas yang tidak hanya memproduksi komoditas barang yang akan dijual, tetapi pada pengorganisasian, konseptualitas dari produksi, distribusi hingga proses konsumsinya. Jadi, tidak hanya fungsi dari sebuah barang menjadi tonggak penilaiain, tetapi aspek lain menjadi pertimbangan dalam pembuatan barang, yakni komoditas. Pada penerapannya, seni juga mengalami proses pertukaran nilai. Terjadi perubahan serta penambahan yang terjadi pada nilai seni itu sendiri. Komodifikasi seni berangsur menjadi komoditas, yang awalnya tidak memperhatikan kuantitas tetapi lebih pada keberadaan. Tetapi, pada eksistensi seni, kuantitas menjadi penting dalam komoditas. Bahkan, kuantitas seni lebih dipehatikan daripada kualitasnya. Anggapan atas "keberadaan" yang didasarkan pada kuantitas masih menjadi stigma yang kuat dalam keberlagsungan seni itu sendiri.

Pada ranah eksistensi yang didasarkan pada seni, pertukaran tidak hanya didasarkan pada tontonan dan konsumsi saja, terdapat konteks baru yang berbaur dan berpadu pada seni, yakni eksistensi dari gaya hidup. Bisa diumpamakan bahwa "nonton seni maka saya ada". Semakin seorang individu menonton seni di tiap harinya, maka individu tersebut dapat dikatakan eksis. Telaah lain juga dapat dikaitkan pada persepsi pada seni itu sendiri, seni dianggap sesuatu yang estetik, rumit dan sebagainya. Jika dilakukan sebuah survei dengan pertanyaan seni itu apa? Maka akan timbul beberapa jawaban yang mengarah kepada estetik, abstrak, rumit, tari kraton, dsb. Stigma seni sebagai sesuatu yang tidak dengan mudah dipahami menjadi nilai baru yang diperebutkan oleh masyarakat, alhasil, acara seni sangat diburu oleh masyarakat. Seni dengan nilai baru (eksistensi gaya hidup) memberikan tambahan nilai yang lebih tinggi, dan ihwal tersebut dimanfaatkan para industrialis global masa kini, dengan peran media sosial.

Tidak terpaku pada perubahan konsep komodifikasi nilai pada seni, sudut pandang komoditas menjadi penting ketika seni termodifikasikan. Menilik artian komoditas itu sendiri, Appadurai (1986:4) berpendapat bahwa"Economic exchange creates value. Value is embodies in commodities that are exchanged. Focusing on the things are exchanged, rather than simply on the forms or functions of exchange, make it possible to argue that what creates the link 
between exchange and value is politics, construed broadly. Commodities like persons, have social lives." Seperti yang dikatakan Appadurai bahwa komoditas sama seperti manusia, dimana mempunyai "kehidupan sosial". Pada ihwal ini Appadurai menekankan tentang nilai pertukaran pada komoditas, ada nilai yang terdapat pada pertukaran. Ihwal ini serupa dengan barter di zaman sekarang, ketika membeli sesuatu dengan harga mahal, barang itu memang mempunyai nilai yang mahal juga, dan sebaliknya. Ihwal ini serupa dengan kuantitas seni, kuantitas yang banyak seturut dengan penonton yang banyak. Tontonan tidak hanya ditujukan untuk menonton saja, tetapi dipertukarkan dengan implikasinya, yakni eksistensi pergaulan. Jika ditelaah secara mendalam, tidak hanya eksistensi saja, pertukaran tidak hanya didasarkan pada penonton dan penyaji, tetapi terdapat teknologi, yaitu media sosial.

Appaduraidalambukunyajugamengangkat pernyataan Marx bahwa adanya perputaran pada komoditas selalu berhubungan dengan uang. Appadurai melihat adanya ihwal diluar uang yang terdapat pada komoditas seperti arena sosial. Appadurai (1986:16) mengklasifikasikan bahwa komoditas terbagi atas empat bentuk, yakni komoditas berdasarkan destinasi, metamorphosis, diversion danex-comodities. Komoditas berdasarkan destinasi adalah barang yang benar-benar murni akan di jual; komoditas metamorphosis adalah barang yang berarti pada sebuah tempat karena mengalami metamorphosis; komoditas diversi adalah barang yang mengalami metamorfosis dan mengalami diversi; komoditas ex-comodities adalah barang yang dipertukarkan ke tempat lain.

Ihwal ini membuktikan bahwa komoditas terbentuk atas jenis barang. Pada persoalan seni, seni mengalami proses komoditas dengan sifat metamorfosis, dimana seni tidak hanya ditukarkan pada nilai seni itu sendiri, tetapi terdapat nilai eksistensi dan teknologi (media sosial) yang menjadi implikasi dalam gaya hidup. Nilai eksistensi gaya hidup menjadi pertimbangan sebuah seni mempunyai eksistensi seni lebih tinggi. Bahkan komoditi seni berimplikasi pada tingginya kuantitas, yang terwakilkan pada acaraacara seni. Menilik perkembangan kegiatan seni yang masif, tontonan seni menjadi tren dan mempunyai pangsa pasar tersendiri dalam tingkat konsumerisme masyarakat yang terus melonjak. Seni dan gaya hidup mempunyai nilai tukar yang tinggi dalam tingkat konsumerisme masyarakat. Dalam telaahnya Soedarso (2006:67) menyatakan bahwa seni adalah segala sesuatu yang dibuat orang bukan karena didorong oleh keinginan untuk memenuhi kebutuhan pokok, melainkan adalah karena desakan kebutuhan sekunder, yaitu, kebutuhan akan kemewahan, kenikmatan, atau kebutuhan spiritual. Ihwal ini merupakan artian dari keberadaan seni yang sebenarnya, dimana seni merupakan kebutuhan sekunder. Tetapi dalam keberadaannya kini, seni yang merupakan kebutuhan sekunder berubah menjadi kebutuhan primer. Seni merupakan kebutuhan yang utama bagi masyarakat. Berselfie dengan objek seni, mempostingnya ke media sosial merupakan langkah mencapai eksistensi masyarakat dewasa kini.

\section{Kesimpulan}

Tidak ada yang salah dalam seni, baik dalam tataran produksi dan konsumsi pada seni. Dewasa kini, reseptor seni tidak terbatas pada satu golongan tetapi banyak golongan, bahkan kini seni sangat digandrungi oleh masyarakat awam. Seni seakan menjadi sebuah kata terjanji dalam kehidupan berelasi masyarakat. Masyarakat awam sebagai reseptor baru mempunyai peran yang kuat dalam eksistensi seni itu sendiri, dan seni menjadi eksistensi bagi masyarakat awam tersebut. Kehadiran teknologi membuat komodifikasi seni menjadi berubah, tidak hanya artian seni dengan resepto, tetapi ada nilai eksistensi dan teknologi ketika mereka 
mengakses seni. Teknologi memudahkan masyarakat dalam mengabadikan momen tertentu, dimulai dengan kamera rol film hingga kamera handphone yang mempunyai kualitas yang baik, membuat sebuah kebiasaan baru, selfie. Sebuah kegiatan foto diri menjadi sebuah gaya hidup baru masyarakat, sejalan dengan teknologi. Seorang individu berfoto dengan sebuah objek merupakan wujud dari selfie. Kebiasaan yang terus menerus membuat selfie menjadi biasa, para pecandu selfie mencari sebuah wahana baru, dan seni menjadi ajang eksistensi mereka.

Selfie dengan objek seni menjadi suatu tindakan yang kerap terlihat dan digandrungi. Tidak lupa setelah selfie mereka menyebarluaskan lewat media sosial yang menyediakan aplikasi pamer foto. Ketika objek wisata atau kegiatan olahraga sudah tidak diminati, pergelaran pertunjukan dan pameran rupa menjadi komoditas baru. Selfie dengan karya dan menyebarluaskan di media sosial menuai sebuah eksistensi yang besar. Dari disposisi ini, selfie dan media sosial menjadi ranah baru dalam beradu eksistensi antar individu. Kebiasaan ini menjadi sebuah gaya hidup baru, bahkan menjadi tindakan yang premier. Masyarakat seni sebaiknya memikirkan sebuah terobosan agar para pelaku selfie dengan objek seni dapat mengartikan seni dengan lebih bermutu, tidak sebatas mempromosikan "secara tidak sengaja".

\section{Daftar Pustaka}

Abdullah, Irwan. (2010). Konstruksi dan Reproduksi Kebudayaan. Yogyakarta: Pustaka Pelajar.

Anderson, Ben. (1991). Imagined Communities. London: Verso

Appadurai, Arjun. (1981). 'Gastro-Politics in Hindu South Asia', American Ethnologist, 8 (3), hl. 494-511.
Barker, Chris. (2005). Cultural Studies Teori dan Praktek (terj.). Yogyakarta: Bentang.

Bourdieu, Pierre. (1996). Distinction: a social critique of the judgment of taste. London: Routledge.

David, Smith, and Evans, Phil. (1982). Marx's Kapital For Beginners. New York: Patheon

Eriyanto. (2008). Konsentrasi Kepemilikan Media dan Ancaman Ruang Publik. Jurnal Ilmu Sosial dan Ilmu Politik. Vol. 12 No. 2. Edisi November.

Fairclough, Norman. (1995). Critical Discourse Analysis: The Critical Study of Language. Longman.

Hauser, Arnold. (1982). The Sociology of Art, terj. Kenneth J. Northcott. London: University of Chicago Press.

Holt, Claire. (2000). Melacak Jejak Perkembangan Seni di Indonesia. Bandung: MSPI.

Soedarso. (2006). Trilogi Seni. Yogyakarta: Badan Penerbit Institut Seni Indonesia Yogyakarta.

Spreadley, James P. (2007). Metode Etnografi. Terj Misbah Zulfa Elizabeth, Yogyakarta: PT. Tiara Wacana.

Sudjojono, S. (2000). Seni Lukis, Kesenian dan Seniman. Yogyakarta: Yayasan Aksara Indonesia.

Sumardjo, Jakob. (2000). Filsafat Seni. Bandung: Penerbit ITB

Tolstoy, Leo N. (1960). What is Art?, NewYork: Bobb- Merrill

Tribun Jogja. 11 Juni, 2014. Nonton Art Jog 2014 Kini Bayar Rp 10.000.

\section{Narasumber}

Yanti, $16^{\text {th }}$ Seorang siswi di salah satu SMA Kota Yogyakarta.

Muhammad, $23^{\text {th }}$ seorang mahasiswa seni di salah satu institusi pendidikan.

Agus, $30^{\text {th }}$ seorang penikmat seni.

Ratna, $26^{\text {th }}$ masyarakat awam. 